\title{
In vitro initial immune response against Leishmania amazonensis infection is characterized by an increased production of IL-10 and IL-13
}

Authors

Zirlane Castelo B Coêlho

Maria Jania Teixeira ${ }^{1}$

Erika Freitas Mota

Mércia Sindeaux

Frutuoso

João Santana da Silva ${ }^{2}$

Aldina Barral $^{3}$

Manoel Barral-Netto ${ }^{3}$

Margarida Maria L

Pompeu

Medical School of Universidade Federal do Ceará, Rua Alexandre Baraúna, 949, Fortaleza, CE 60430-160, Brazil.

${ }^{2}$ Medical School of Ribeirão Preto, Universidade de São Paulo, Av. Bandeirantes, 3900, Ribeirão Preto, SP 14049-900, Brazil. ${ }^{3}$ Centro de Pesquisas Gonçalo Moniz, Fundação Oswaldo Cruz (FIOCRUZ), Rua Waldemar Falcão, 121, Salvador, BA 40296-710, Brazil.
Submitted on: $3 / 5 / 2010$ Approved on: 8/2/2010

Correspondence to: Maria Jania Teixeira Phone.: +55-85-33668311 Fax: +55-85-33668316 E-mail: mjteixeira601@ gmail.com

This study received financial support from the CAPES (Coordenação de Aperfeiçoamento de Pessoal de Nível Superior from Portuguese) PROCAD 0018/01-5, and $\mathrm{CNPq}$ (Conselho Nacional de Desenvolvimento Científico e Tecnológico from Portuguese).

\begin{abstract}
The initial encounter of Leishmania with its host's immune system is important in the outcome of infection. Previous studies have shown that PBMCs from healthy volunteers (HV) exposed to Leishmania differ in IFN- $\gamma$ production. We have expanded such observations evaluating the profile and kinetics of cytokines (IFN- $\gamma$, IL-12p70, IL-10, IL-13), chemokines (CCL5, CCL3, CCL4, CXCL10), and chemokine receptors (CCR1,CCR5, CXCR3, CCR4) in vitro L. amazonensis-stimulated of HV's PBMCs. HVs were divided in groups of high (HR) or low (LR) IFN- $\gamma$ responders. In both groups, HR and LR, after L. amazonensis infection there was a predominance of IL-10 and IL-13 over IFN- $\gamma$ production, while IL-12 was produced in similar amount. Regarding chemokines, a more striking difference was observed for CCL3 expression that was lower at 12 hours and 48 hours post infection in LR than in HR. Interestingly, a downregulation of CCR5 and a greater expression of CCR4 were found in low IFN- $\gamma$ responders. These data suggest that early after L. amazonensis infection there is a cytokine milieu dominated by IL-13 and IL-10, and despite of this environment, IFN- $\gamma$ is produced, supporting the complexity of the response. It is noteworthy that the pattern of immune response is mounted in first hours after Leishmania stimulation, with the definition of the differentiation of Th1 versus Th2 cells. It remains to be determined if such an in vitro difference has an in vivo counterpart in terms of susceptibility to infection.
\end{abstract}

Keywords: Leishmania amazonensis, interleukin-10, interleukin-13.

[Braz J Infect Dis 2010;14(5):476-482] @Elsevier Editora Ltda.

\section{INTRODUCTION}

Leishmania parasites preferentially reside as an amastigote in phagocytic cells such as macrophages, resulting in diverse clinical manifestations. The severity of disease is dependent on both causative species of parasite and immunological status of the host. ${ }^{1}$ L. amazonensis is the etiologic agent of anergic diffuse cutaneous leishmaniasis in the New World, a condition that is associated with specific impairment of the cell-mediated immune response. ${ }^{2,3}$

Protection and healing in human and experimental cutaneous leishmaniasis correlates to the development of Th1 immune response, and IFN- $\gamma$ is considered the pivotal molecule in such process. ${ }^{4,5}$ In contrast, a Th2 response with IL-4 and IL-10 production often results in disease progression. ${ }^{5}$ Of note, IFN- $\gamma$ production following Leishmania contact differs among naive individuals; some are high IFN- $\gamma$ responders, whereas others produce low amounts of this cytokine. ${ }^{6}$ This observation has been docu- mented with several species of Leishmania, as well as in individuals naturally infected, in the initial phase of the infection. . $^{7,8,9,10}$

Understanding the initial steps of the human immune response against Leishmania may be useful in design rational approaches to vaccination against the disease. Several approaches have been used in developing a vaccine against leishmaniasis, including some which lead to considerable IFN- $\gamma$ production, however, up to now, there are no effective vaccines. ${ }^{11,12}$ Thus, the understanding of the early events besides IFN- $\gamma$ production are of utmost importance, and the in vitro priming system using human cells may be useful in such attempts.

Chemokines and chemokine receptors have a fundamental role in the development and regulation of immune and inflammatory responses and have received a great deal of attention in both human and experimental leishmaniasis. ${ }^{13}$ There is strong evidence that some chemokines are also involved in polarized 
immune responses. ${ }^{14}$ Chemokine receptors are differentially expressed on polarized Th cells. Typically, CXCR3 and CCR5 are preferentially expressed on polarized Th1 cells, whereas CCR3, CCR4 and CCR8 have been associated with the Th2 phenotype. ${ }^{14}$ However, little is known about the expression profiles of these mediators in L. amazonensis-infected individuals and in the human in vitro priming system.

In order to better understand the early events on the host-parasite interactions, in this paper, we evaluated the production of proinflammatory (IFN- $\gamma$, IL-12p70, CCL3, CCL4, CCL5, CXCL10) and of anti-inflammatory (IL-10, IL-13) cytokines, chemokines and chemokine receptors taking advantage of the in vitro priming system using peripheral blood mononuclear cells (PBMCs) from healthy individuals stimulated by live promastigotes of L. amazonensis.

\section{MATERIALS AND METHODS}

\section{Human cells}

Fourteen buffy coats were obtained from healthy individuals by Centro de Hemoterapia e Hematologia do Ceará (HEMOCE), Fortaleza, Ceará, Brazil. All individuals had a proliferation index of $\leq 5$ when stimulated with Leishmania antigens. Serology results were negative for leishmaniasis, Chagas' disease, hepatitis, and human immunodeficiency virus. The study was approved by the Human Research Ethics Committee of the Universidade Federal do Ceará, Brazil.

\section{In vitro sensitization of human cells to Leishmania}

In vitro sensitization to Leishmania was performed by using the protocol described by Pompeu et al. ${ }^{6}$ with some modifications. Briefly, PBMCs were obtained by using a Ficoll-Hypaque gradient (Sigma Aldrich) at $1,500 \mathrm{rpm}, 21^{\circ} \mathrm{C}$, per 30 minutes. The cells were washed three times, and resuspended in RPMI 1640 medium supplemented with 10mM HEPES, $100 \mathrm{U} / \mathrm{mL}$ penicillin, $200 \mu \mathrm{g} / \mathrm{mL}$ streptomycin, $2 \mathrm{mM} \mathrm{L}$-glutamine (all from Sigma Aldrich), $50 \mu \mathrm{g} / \mathrm{mL}$ gentamicin (Gibco BRL), and $10 \% \mathrm{AB}$ inactivated human serum. PBMCs were placed in 24well plates (Costar, Corning Inc., Acton, MA) at a final concentration of $5 \times 10^{6}$ cell $/ \mathrm{mL}(1 \mathrm{~mL} /$ well $)$ and incubated for 5 days with and without live promastigotes (final concentration of $5 \times 10^{6}$ cells $/ \mathrm{mL}$ ) at $37^{\circ} \mathrm{C}$ at $5 \% \mathrm{CO}_{2}$.

\section{Lymphocytes proliferation assay}

PBMCs were cultivated in triplicates at a concentration of $5 \times 10^{5}$ cell/well and stimulated with live promastigotes $\left(5 \times 10^{5}\right.$ cell/well), or $20 \mu \mathrm{g} / \mathrm{mL}$ of concanavalin A (Sigma Aldrich), or no stimulated in 96-plates well (Costar). Five days after initiation of the cultures, $0.2 \mu \mathrm{Ci}^{3} \mathrm{H}$-thymidine were added to assays and incubated for the overnight. Cells were collected on glassfiber filters (Skatron Inst., Sterling, VA) using a Cell Harvester (Cambridge Technology Inc., USA) and quantified in liquid scintillation counter (Beckmann LS 6000). Only the samples with index proliferation $\leq 5$ were used for the other tests.

\section{Measurement of cytokines by ELISA}

The supernatants were harvested after 12, 48, and 120 hours for determination of IFN- $\gamma$, IL-10, IL-12p70, and IL-13 production and stored at $-20^{\circ} \mathrm{C}$ until use. The cytokine production was quantified by ELISA (BD Bioscences PharMingen, San Jose, $\mathrm{CA}$ ) according to the manufacturer's instructions. The sensitivity of the ELISA was $1 \mathrm{pg} / \mathrm{mL}$ (IFN- $\gamma$ and IL-13), $4 \mathrm{pg} / \mathrm{mL}$ (IL$12 \mathrm{p} 70$ ), and $2 \mathrm{pg} / \mathrm{mL}$ (IL-10). Results are presented as differences in the cytokine production between cells stimulated with L. amazonensis and controls without any stimulation.

\section{Oligonucleotide primers}

Oligonucleotide primers specific for human chemokines and chemokine receptors were used to amplify cDNA by PCR. $\beta$-actin primers were used as a control to evaluate the expression of a housekeeping gene. The primers for chemokines, chemokine receptors and $\beta$-actin (Table 1) were prepared from Invitrogen Life Technologies (São Paulo, SP, Brazil).

Table 1. Primer sequences and the sizes of PCR products

\begin{tabular}{lccc}
\hline Oligonucleotide & \multicolumn{1}{c}{ Sense primer $\left(\mathbf{5}^{\prime} \mathbf{- 3}^{\prime} \mathbf{)}\right.$} & Antisense primer $\left(\mathbf{3}^{\prime} \mathbf{- 5}^{\prime} \mathbf{)}\right.$ & Product size (bp) \\
\hline$\beta$-actin & ATG TTT GAG ACC TTC AAC AC & CAC GTC ACA CTT CAT GAT GG & 495 \\
\hline CCL3/MIP-1 $\alpha$ & ACC ATG GCT CTC TGC AAC CA & TTA AGA AGA GTC CCA CAG TG & 391 \\
\hline CCL4/MIP-1 $\beta$ & CCT GCT GCT TTT CTT CAC CC & CAC CTA ATA CAA TAA CAC GGC & 336 \\
\hline CCL5/RANTES & TCA TTG CTA CTG CCC TCT GC & CGT CGT GGT CAG AAT CTG GG & 373 \\
\hline CXCL10/IP-10 & CCT GCT TCA AAT ATT TCC CT & CCT TCC TGT ATG TGT TTG GA & 229 \\
\hline CCR1 & CCT TCT GGA TCG ACT ACA AGT T & GTA GCA GAT GAT CAT GAC CAA C & 396 \\
\hline CCR4 & GGA TAT AGC AGA TAC CAC CCT C & AAA TCA TCT TGC ACA GAC CTA G & 329 \\
\hline CCR5 & GGC TGT GAC GCT TAT CTT CAC C & CGT GTC ACA AGC CCA CAG ATA T & 368 \\
\hline CXCR3 & TAG AAG TTG ATG TTG AAG AGG G & CAG CTC TTC CTA TGA CTA TGG A & 339 \\
\hline
\end{tabular}




\section{RNA isolation and cDNA preparation by Reverse Transcription (RT)}

Total RNA was extracted from culture cells using TRIZOL reagent (Invitrogen Life Technologies), according to manufacturer's instruction. Briefly, after cell lysis, RNA was precipitated with isopropanol, washed with $70 \%$ ethanol, and dissolved into diethylpyrocarbonatetreated water. RNA concentration and purity was determined by measuring at $\mathrm{A}_{260}$ and $\mathrm{A}_{280}$, and samples were immediately stored at $-70^{\circ} \mathrm{C}$. cDNA synthesis was performed on $2 \mu \mathrm{g}$ of RNA in a total volume of $23 \mu \mathrm{L}$ containing $50 \mathrm{mM}$ of oligo (dT) ${ }_{12-18}$ primers (Promega, Madison, WI), $2.5 \mathrm{mM}$ dNTPs (Invitrogen), 1x firststrand buffer $(20 \mathrm{mM}$ Tris-HCl, $\mathrm{pH} 8.4,50 \mathrm{mM} \mathrm{KCl}$, $2 \mathrm{mM} \mathrm{MgCl}$ ), $20 \mathrm{U}$ of ribonuclease inhibitor, and 200 $\mathrm{U} / \mu \mathrm{L}$ of reverse transcriptase (Promega). The reaction mixture was incubated at $42^{\circ} \mathrm{C}$ for $50 \mathrm{~min}$ and stopped at $95^{\circ} \mathrm{C}$ for $5 \mathrm{~min}$.

\section{Chemokine and chemokine receptors mRNA detection}

Expression of mRNA was analyzed by reverse transcriptase-polymerase chain reaction (RT-PCR) for the following: CXCL10, CCL3, CCL4, CCL5, CCR1, CCR4, CCR5, CXCR3 and $\beta$-actin. A $5 \mu \mathrm{L}$ aliquot of the cDNA obtained was amplified in a $25 \mu \mathrm{L}$ reaction containing 1x PCR buffer $(5 \mathrm{nmol} \mathrm{KCl}, 1 \mathrm{nmol}$ Tris- $\mathrm{HCl}, \mathrm{pH} 8.4$, $\left.1.5 \mathrm{nmol} \mathrm{MgCl}_{2}\right), 0.2 \mathrm{nmol}$ each dNTP, $200 \mathrm{nmol}$ each primer, and $5 \mathrm{U}$ of Taq DNA polymerase (Promega) in a PTC-100 thermal cycler (MJ Research Inc., Waltham, MA). Reaction conditions were 25 cycles of $1 \mathrm{~min}$ at $94^{\circ} \mathrm{C}$, $1 \mathrm{~min}$ at $55^{\circ} \mathrm{C}$, and $2 \mathrm{~min}$ at $72^{\circ} \mathrm{C}$, with a final extension step of $7 \mathrm{~min}$ at $72^{\circ} \mathrm{C}$. For each set of primers, a negative sample (water) was run in parallel. PCR products were visualized by UV light after electrophoresis through a $6 \%$ acrylamide gel and stained with silver nitrate. The sizes of the RT-PCR products were confirmed by comparison with a 100-bp ladder run in parallel on the same gel. The band intensity of the amplified products was analyzed using EagleSight ${ }^{\circledR}$, version 3.2 software (Stratagene, La Jolla, CA). The results are expressed as a ratio of expression of chemokine or chemokine receptor to $\beta$-actin expression.

\section{Statistical analysis}

The data are presented as mean \pm standard error of the mean. Analysis between high and low producers was performed by using the Mann-Whitney- test. For all statistical analysis we used GraphPad Prism, version 5.00 for Windows (GraphPad Software, San Diego, CA) and a $\mathrm{p}$ value $<0.05$ or $<0.01$ was considered significant.

\section{RESULTS}

\section{Defining high and low IFN- $\gamma$ responders}

The groups were defined by the concentration of IFN- $\gamma$ produced after $120 \mathrm{~h}$ of stimulation with L. amazonensis promastigotes. It was adopted as criterion of the division of the groups the same used by Pompeu et al. ${ }^{6}$ Individuals with IFN- $\gamma$ greater than $160 \mathrm{pg} / \mathrm{mL}$ were classified as high responders $(\mathrm{n}=7)$ and those with lower amount production as low responders $(\mathrm{n}=$ 7). In this study, PBMCs from high responders secreted IFN- $\gamma$ at concentrations ranging from 160 to $584 \mathrm{pg} / \mathrm{mL}$, while in low responders the IFN- $\gamma$-secreted ranged from 10 to $135 \mathrm{pg} / \mathrm{mL}$.

\section{Production of cytokines by PBMCs during in vitro L. amazonensis infection}

The levels of anti-inflammatory cytokines, IL-10 and IL-13, as well as the levels of inflammatory cytokines, IFN- $\gamma$ and IL-12 were measured after 12, 48 and 120 hours of sensitization in vitro. At 12 hours of infection it was already possible to observe the production of all the cytokines evaluated, coinciding with the peak level of IL-12 in both groups. Secretion of IL-10 and IL-13 reached their peak levels after 48 hours, maintaining a greater response in low than in high responders (Figure 1). Consistent with previous reports, ${ }^{6,7,8,9}$ the levels of IFN- $\gamma$ in low responders were always lower than levels in high responders, while IL12 was produced in similar amount (Figure 1). However, it is worth to point out that after L. amazonensis infection, in both groups, high and low responders, there was a predominance of IL-13 and IL-10 over IFN- $\gamma$ production (Figure 1).

Figure 1: Cytokine production by PBMCs from high $(\mathrm{n}=7)$ and low $(\mathrm{n}=7)$ IFN- $\gamma$ responders. PBMCs from different donors were stimulated with or without live L. amazonensis promastigotes. After 12, 48 and 120 hours supernatants were assayed for IFN-g, IL-12p70, IL-13, and IL-10 production. Results were obtained by an enzyme-linked immunosorbent assay and are expressed as the mean \pm standard error of the mean. Significant difference $(\mathrm{p}<0.05)$ between high and low IFN- $\gamma$ responders are indicated by asterisks. The experiment is representative of at least three independent experiments.
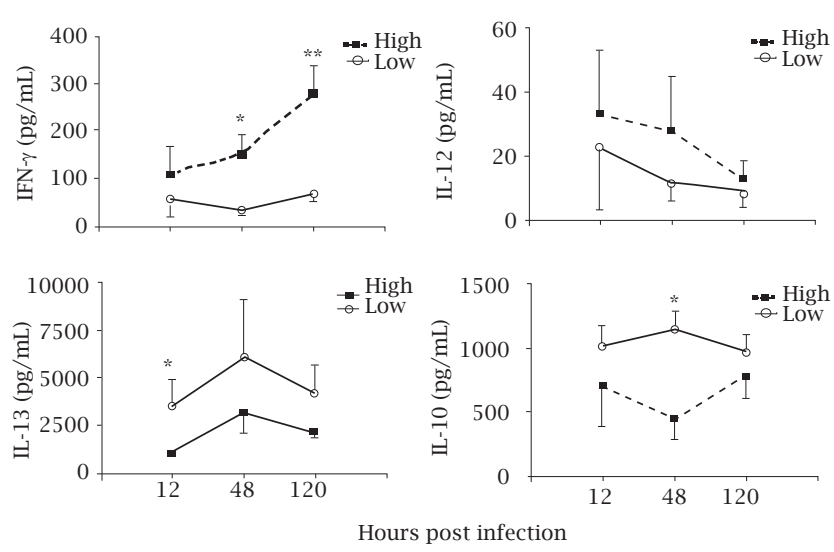


\section{Expression of chemokines and chemokine receptors during in vitro L. amazonensis infection}

Chemokines ligands for CCR5 (CCL3, CCL4, and CCL5) or CCR1 (CCL3, and CCL5) are involved in differentiation of T-cell subsets, and recruitment of leukocytes to the site of infection whereas CXCL10 is a NK cell-activating chemokine. ${ }^{16}$ We next examined whether the expression of these chemokines and their receptors was correlated with Th2 profile presented by low and high responders of IFN- $\gamma$ after L. amazonensis infection. It is interesting that CCL3 and CCL4 showed the same response pattern in both groups. A more striking difference was observed for
CCL3 expression; in this case, expression of this chemokine in low responders was significantly lower at 12 and $48 \mathrm{~h}$ post infection than in high producers (Figure 2).

Regarding expression of chemokine receptors, the principal finding was an almost complete downregulation of CCR5 in low responders at all time points evaluated in this study (Figure 3). Moreover, we found a greater expression of CCR4 (Th2-related) in low responders during the whole period of evaluation, with a statistically significant difference $(p=0.015)$ at 120 hours. CCR1 and CXCR3 did not present a difference between the two groups.

Figure 2: Semi-quantitative RT-PCR analysis of the expression of chemokines from PBMCs from high and low IFN- $\gamma$ responders Densitometric data of chemokines expression at 12, 48, and 120 hours post infection are represented as the mean \pm standard error of the mean of the ratio of chemokine to $\beta$-actin band from PBMCs from high and low IFN- $\gamma$ responders. The profiles are representative of at least three independent experiments. The asterisks indicate significant differences $(* \mathrm{p}<0.050)$ between high and low IFN- $\gamma$ responders.
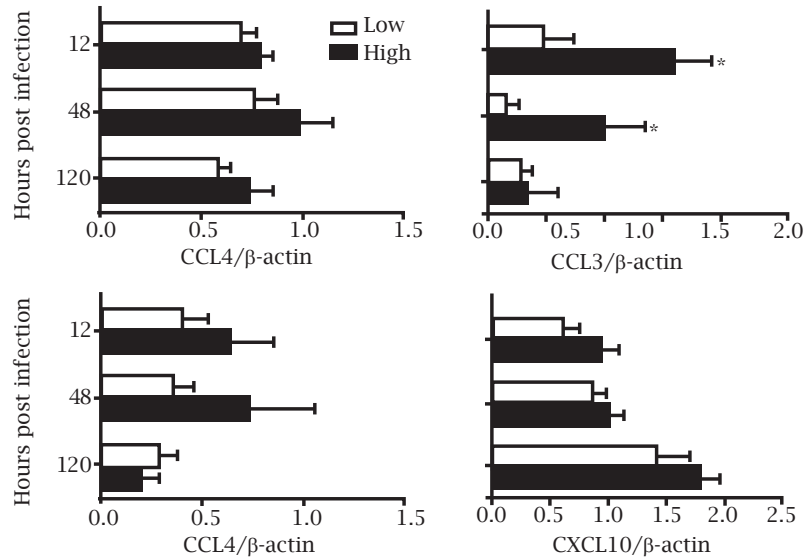

Figure 3: Semi-quantitative RT-PCR analysis of the expression of chemokine receptors from PBMCs from high and low IFN- $\gamma$ responders. Densitometric data of chemokine receptors expression at 12, 48, and 120 hours post infection are represented as the mean \pm standard error of the mean of the ratio of chemokine receptors to $\beta$-actin band from PBMCs from high and low IFN- $\gamma$ responders. The profiles are representative of at least three independent experiments. The asterisks indicate significant differences $(* \mathrm{p}<0.050)$ between high and low IFN- $\gamma$ responders.
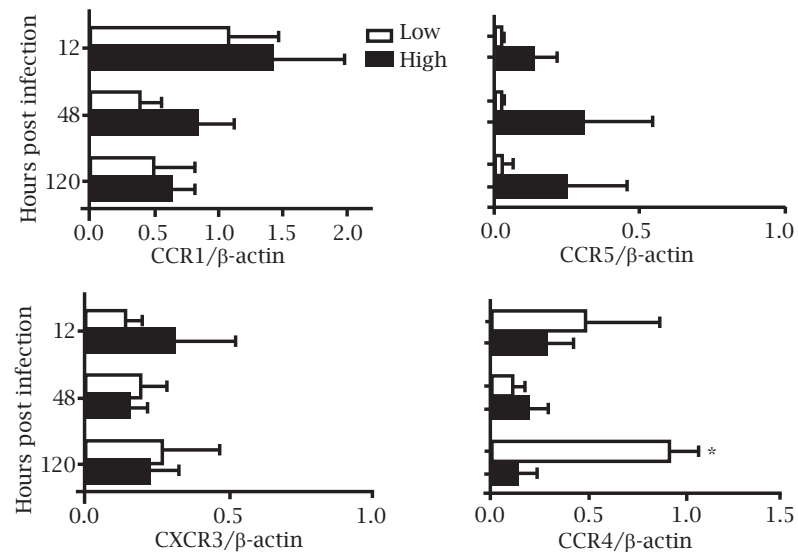


\section{DISCUSSION}

The present report shows that few hours following exposure to L. amazonensis, PBMCs from naive volunteers presented a predominant Th2 response. Such response is supported by a high production of IL-13 and IL-10 followed by a low IL-12 production. However, despite of this cytokine milieu, IFN- $\gamma$ was produced.

Th2 cytokine IL-13 is involved in susceptibility to infection with several species of Leishmania and the use of IL-13 deficient mice and IL-13 transgenic mice demonstrated that IL-13 is important for the generation of Th2 cells. ${ }^{17-19}$ Since IL-13 is a downregulating factor of macrophages function, ${ }^{20}$ production of IL-13 after L. amazonensis infection might be, in part, a mechanism used by the parasite to evade the immune system.

IL-12 is the key cytokine for induction of Th1 immunity. Although IL-12 was initially detected in macrophages, several reports have shown that dendritic cells (DC) are the primary source of IL-12 in leishmaniasis. ${ }^{21-23}$ Indeed, IL-12 and related cytokines (IL-23, IL-27, and IL-1) are primarily released by infected DC very early on post infection by Leishmania, thus efficiently inducing Th1-mediated protection. ${ }^{24-26}$ In this current report, although IL-12 was also secreted by low and high responders, it is tempting to hypothesize that the higher levels of IL-13 can render specific T cells unresponsive to IL-12 by inhibiting the expression of the IL-12 receptor $\beta$-subunit (IL-12R $\beta 2$ ) chain, as already demonstrated by others, ${ }^{27-30}$ favoring the formation of a microenvironment which promotes early the differentiation of Th2 cells and consequently a lower production of IFN- $\gamma$.

IL-10, which was produced in higher levels after L. amazonensis infection in both groups, usually exhibits human macrophage-deactivating properties, ${ }^{31}$ and also plays a regulatory role in leishmaniasis. ${ }^{5,32}$ High intralesional levels of IL-10 are associated to the persistence of the parasite, even in mice genetically resistant to L. major infection..$^{33}$ In human localized cutaneous leishmaniasis, Leishmania persistence and high intralesional IL-10 expression is associated with severity and unresponsiveness to treatment of Leishmania infection. ${ }^{34,35}$ High levels of these cytokines during the first 48 hours of infection with L. amazonensis may contribute to parasite survival in macrophages and disease progression.

In this study, IL-4 production was not evaluated. Although it was initially thought that IL-4 was required for the development of Th2 response and the differentiation of naive $\mathrm{T}$ cells into Th2 cells, further research has shown that IL-4 knockout mice are capable of mounting Th2 response, ${ }^{36,37}$ and DC can induce in vivo development of Th2 cells in the absence of IL$4,^{38}$ suggesting that IL-4 is not required for the initiation of Th2 response and other cytokines such as IL-13 and IL-2 influence the development of Th2 response. ${ }^{39}$ Indeed, protective roles for IL-4 and IL-13 have been described during L. major and $L$. donovani infections but not during $L$. mexicana or
L. amazonensis infections ${ }^{40,41}$ and some workers have shown that, under certain circumstances, IL-4 is capable of directing Th1 response. ${ }^{42}$ It suggests that the significance of the type 2 responses to the outcome of infection with Leishmania is dependent on the strain or species of parasite studied. ${ }^{2}$

Low IFN- $\gamma$ responders displayed lower expression of CCL3 and CCL4 than high responders. Additionally, a stressed suppression of CCR5 seems to have an important role in the induction of Th2 response in the first hours of in vitro lymphocytes sensitization by L. amazonensis. CCL3 and CCL4 are known as being involved in the development of Th1 cells. ${ }^{43}$ Linkage of CCL3 or CCL5 to CCR5 and CCR 1 leads mainly to early IFN- $\gamma$ production by NK cells. ${ }^{16}$ It is worth to point out that although CCR1 expression occurred in low responders, its chemokine ligand (CCL3) was not expressed in those individuals.

Interestingly, low IFN- $\gamma$ responders presented upregulation for CCR4 that had a higher expression in low than in high responders at practically all time points evaluated in this study. CCR4 is a chemokine receptor found on DC, macrophages, NK cells, and basophiles, but it is predominantly known for its expression on $\mathrm{T}$ cells, especially of the Th2 phenotype. ${ }^{44}$

CXCL10 and its receptor (CXCR3) were expressed in low responders, and since this chemokine is capable of recruiting and activating NK cells, ${ }^{45}$ which are IFN- $\gamma$ producers, ${ }^{46}$ we speculate that IFN- $\gamma$ levels observed in these individuals is being produced by NK cells. However, this production is not maintained in low responders probably due to a decrease in IL-12 production in these individuals.

It had been demonstrated that L. amazonensis-infected mice presented significantly delayed and depressed expression of inflammatory cytokines (IL-12, IFN- $\gamma$, IL-1 $\alpha$, IL-1 $\beta$ ), chemokines (CCL3, CCL4, CCL5, and MIP-2), and chemokine receptors (CCR1, CCR2, CCR5) in foot tissues and draining lymph nodes compared to the expression in $L$. major-infected controls. ${ }^{47}$ The authors suggest that there is impairment in multiple immune functions at early stages of infection with L. amazonensis parasites.

Collectively, the findings presented here suggest that the pattern of immune response to human cutaneous leishmaniasis due to L. amazonensis is mounted in the first hours after parasite stimulation with a strong Th2 response, supported by a predominance of IL-13 and IL-10 production, and a decreased secretion of IFN- $\gamma$ and IL-12, the signature cytokines for Th1 responses. These date suggest that in the early phase of L. amazonensis infection macrophages can be being activated by the "alternative" via, ${ }^{48}$ which leads to upregulation of genes for TGF- $\beta$ and the enzyme arginase-1, and downregulation of TNF- $\alpha$, thus contrasting the effects of IFN- $\gamma$, which induces upregulation of iNOS2 enzyme and TNF- $\alpha$, and downregulation of the immunosuppressive TGF- $\beta{ }^{48}$ Furthermore, IL- 4 and IL-13 have also been 
reported to regulate the iron metabolism of activated macrophages by increasing transferrin mRNA expression and ferritin translation, ${ }^{49}$ thus leading to iron depletion and consequently downregulation of macrophage effector functions. Besides, recently it has been shown that high concentrations of IL-10 can enhance IFN- $\gamma$-induced NO production, and even low concentrations of Th2 cytokines are capable of exerting a strong inhibitory effect on both NO production and microbicidal activity of macrophages. ${ }^{50}$ This means that the levels of Th2 cytokines in vivo are critical even when in the presence of a strong IFN- $\gamma$ response.

Interestingly, despite of this early Th2 environment, IFN- $\gamma$ was produced, mainly in high IFN- $\gamma$ responders. These data correlate with what it is known in murine and human L. braziliensis infection, since after a short period of a down modulated immune response, a strong type 1 immune response is predominate later. ${ }^{9,51}$ The correlation between the in vitro difference and the response in vivo in terms of susceptibility to infection remains to be determined. Further studies are required to establish the mechanisms of protection in leishmaniasis and their surrogate markers. This complex interplay of cytokine activities reflects the overall complexity of the immune response to leishmaniasis and ultimately determines the outcome of the infection.

\section{ACKNOWLEDGMENTS}

This study received financial support from the Coordenação de Aperfeiçoamento de Pessoal de Nivel Superior (CAPES PROCAD 0018/01-5), and Conselho Nacional de Desenvolvimento Científico e Tecnológico (CNPq). We thank Cristiane M. Millanezi for technical assistance, and Clarissa R. Teixeira for the critical review of this manuscript.

\section{REFERENCES}

1. McMahon-Pratt D., Alexander J. Does the Leishmania major paradigm of pathogenesis and protection hold for New World cutaneous leishmaniasis or the visceral disease? Immunol Rev 2004; 201:206-24.

2. Silveira FT, Lainson R, De Castro Gomes CM, Laurenti MD, Corbett CE. Immunopathogenic competences of Leishmania $(V$ ) braziliensis and $L$. (L.) amazonensis in American cutaneous leishmaniasis. Parasite Immunol 2009; 31:423-31.

3. Pinheiro RO, Pinto EF, Benedito AB, Lopes UG, Rossi-Bergmann B. The T-cell anergy induced by Leishmania amazonensis antigens is related with defective antigen presentation and apoptosis. An Acad Bras Cienc 2004; 76:519-27.

4. Sacks D, Noben-Trauth N. The immunology of susceptibility and resistance to Leishmania major in mice. Nat Rev Immunol 2002; 2:845-58.

5. Tripathi P, Singh V, Naik S. Immune response to Leishmania: paradox rather than paradigm. FEMS Immunol Med Microbiol 2007; 51:229-42.

6. Pompeu MML, Brodskyn C, Teixeira MJ et al. Differences in gamma interferon production in vitro predict the pace of the in vitro response to Leishmania amazonensis in healthy volunteers. Infect Immun 2001; 69:7453-60.

7. Bourreau E, Prévot G, Pradinaud R, Launois P. Interleukin (IL)-13 is the predominant Th2 cytokine in localized cutaneous leishmaniasis lesions and renders specific CD4+ T cells unresponsive to IL-12. J Infect Dis 2001; 183:953-9.

8. Mahmoodi M, Rajabalian S, Fekri A, Esfandiarpour I. Evaluation of in vitro production of IFN- $\gamma$, IL-10, IL-12 and IL-13 by blood cells in patients with cutaneous leishmaniasis lesions. Iran J Allergy Asthma Immunol 2005; 4:15-21.

9. Rocha PN, Almeida RP, Bacellar O et al. Down-regulation of Th1 type of response in early human American cutaneous leishmaniasis. J Infect Dis 1999; 180:1731-4.

10. Rogers KA, Titus RG. Characterization of the early cellular immune response to Leishmania major using peripheral blood mononuclear cells from Leishmania-naive humans. Am J Trop Med Hyg 2004; 71:568-76.

11. Khamesipour A, Rafati S, Davoudi N, Maboudi F, Modabber F. Leishmaniasis vaccine candidates for development: a global overview. Indian J Med Res 2006; 123:423-38.

12. Launois P, Tacchini-CottierF, Kieny MP. Cutaneous leishmaniasis: progress towards a vaccine. Expert Rev Vaccines 2008; 7:1277-87.

13. Teixeira MJ, Teixeira CR, Andrade BB, Barral-Netto M, Barral A. Chemokines in host-parasite interactions in leishmaniasis. Trends Parasitol 2006; 22:32-40.

14. Mantovani A, SicaA, SozzaniS, AllavenaP, VecchiA, Locati M. The chemokine system in diverse forms of macrophage activation and polarization. Trends Immunol 2004; 25:677-86.

15. Almeida RP, Barral-Netto M, De Jesus AM, De Freitas LA, Carvalho EM, Barral A. Biological behavior of Leishmania amazonensis isolated from humans with cutaneous, mucosal, or visceral leishmaniasis in BALB/C mice. Am J Trop Med Hyg 1996; 54:178-84.

16. Muller K, van Zandbergen G, Hansen B et al. Chemokines, natural killer cells and granulocytes in the early course of Leishmania major infection in mice. Med Microbiol Immunol 2001; 190:73-6.

17. Alexander J, Brombacher F, McGachy HA, McKenzie AN, Walker W, Carter KC. An essential role for IL-13 in maintaining a non-healing response following Leishmania mexicana infection. Eur J Immunol 2002; 32:2923-33.

18. Matthews DJ, Emson CL, McKenzie GJ, Jolin HE, Blackwell JM, McKenzie AN. IL-13 is a susceptibility factor for Leishmania major infection. J Immunol 2000; 164:1458-62.

19. Murray HW, Tsai CW, Liu J, Ma X. Visceral Leishmania donovani infection in interleukin-13-/- mice. Infect Immun 2006; 74:2487-90.

20. Martinez FO, Sica A, Mantovani A, Locati M. Macrophage activation and polarization. Front Biosci 2008; 13:453-61.

21. von Stebut E, Belkaid Y, Jakob T, Sacks DL, Udey MC. Uptake of Leishmania major amastigotes results in activation and interleukin 12 release from murine skin-derived dendritic cells: implications for the initiation of anti-Leishmania immunity. J Exp Med 1998; 188:1547-52.

22. Marovich MA, McDowell MA, Thomas EK, Nutman TB. IL12 p70 production by Leishmania major-harboring human dendritic cells is a CD40/CD40 ligand-dependent process. J Immunol 2000; 164:5858-65.

23. Quinones M, Ahuja SK, Melby PC, Pate L, Reddick RL., Ahuja SS. Preformed membrane-associated stores of interleukin (IL)12 are a previously unrecognized source of bioactive IL- 12 that is mobilized within minutes of contact with an intracellular parasite. J Exp Med 2000; 192:507-16. 
24. von Stebut E, Belkaid Y, Nguyen BV, Cushing M, Sacks DL, Udey MC. Leishmania major-infected murine Langerhans cell-like dendritic cells from susceptible mice release IL-12 after infection and vaccinate against experimental cutaneous Leishmaniasis. Eur J Immunol 2000; 30:3498-506.

25. Ahuja SS, Reddick RL, Sato N et al. Dendritic cell (DC)-based anti-infective strategies: DCs engineered to secrete IL-12 are a potent vaccine in a murine model of an intracellular infection. J Immunol 1999; 163:3890-7.

26. von Stebut E, Ehrchen JM, Belkaid Y et al. Interleukin 1alpha promotes Th1 differentiation and inhibits disease progression in Leishmania major-susceptible BALB/c mice. J Exp Med 2003; 198:191-9.

27. Jones D, Elloso MM, Showe L, Williams D, Trinchieri G, Scott P. Differential regulation of the interleukin-12 receptor during the innate immune response to Leishmania major. Infect Immun 1998; 66:3818-24.

28. Himmelrich H, Parra-Lopez C, Tacchini-Cottier F, Louis JA, Launois $\mathrm{P}$. The IL-4 rapidly produced in BALB/c mice after infection with Leishmania major down-regulates IL-12 receptor beta 2-chain expression on CD4+ T cells resulting in a state of unresponsiveness to IL-12. J Immunol 1998; 161:6156-63.

29. Louis J, Himmelrich H, Parra-Lopez C, Tacchini-Cottier F, Launois P. Regulation of protective immunity against Leishmania major in mice. Curr Opin Immunol 1998; 10:459-64.

30. Bourreau E., Prévot G.,Pradinaud R., Launois P. Unresponsiveness of specific T cells to IL-12 is associated with active cutaneous leishmaniasis owing to Leishmania guyanensis. Scand J Immunol 2001; 54:335-9.

31. Lacki JK, Wiktorowicz KE. Biological properties of interleukin 10. Postepy Hig Med Dosw 1994; 48:363-70.

32. Nylén S, Sacks D. Interleukin-10 and the pathogenesis of human visceral leishmaniasis. Trends Immunol 2007; 28:378-84.

33. Belkaid Y, Hoffmann KF, Mendez S et al. The role of interleukin (IL)-10 in the persistence of Leishmania major in the skin after healing and the therapeutic potential of anti-IL-10 receptor antibody for sterile cure. J Exp Med 2001; 194:1497-1506.

34. Bourreau E, Prévot G, Gardon J, Pradinaud R, Launois P. High intralesional interleukin-10 messenger RNA expression in localized cutaneous leishmaniasis is associated with unresponsiveness to treatment. J Infect Dis 2001; 184:1628-30.

35. Gomes-Silva A, de Cássia Bittar R, Dos Santos RN et al. Can interferon-gamma and interleukin-10 balance be associated with severity of human Leishmania (Viannia) braziliensis infection? Clin Exp Immunol 2007; 149:440-4.

36. Mohrs M, Holscher C, Brombacher F. Interleukin-4 receptor alpha-deficient BALB/c mice show an unimpaired T helper 2 polarization in response to Leishmania major infection. Infect Immun 2000; 68:1773-80.
37. Noben-Trauth N, Kropf P, Muller I. Susceptibility to Leishmania major infection in interleukin-4-deficient mice. Science 1996; 271:987-90.

38. Rissoan MC, Soumelis V, Kadowaki N et al. Reciprocal control of T helper cell and dendritic cell differentiation. Science 1999; 283:1183-86.

39. Sacks D, Anderson C. Re-examination of the immunosuppressive mechanisms mediating non-cure of Leishmania infection in mice. Immunol Rev 2004; 201:225-8.

40. Alexander J, Carter KC, Al-Fasi N, Satoskar A, Brombacher F. Endogenous IL-4 is necessary for effective drug therapy against visceral leishmaniasis. Eur J Immunol 2000; 30:2935-43.

41. Stager S, Alexander J, Carter KC, Brombacher F, Kay PM. Both interleukin-4 (IL-4) and IL-4 receptor alpha signaling contribute to the development of hepatic granuloma with optimal anti-leishmanial activity. Infect Immun 2003; 71:4804-7.

42. Biedermann T, Zimmermann S, Himmelrich H et al. IL-4 instructs TH1 responses and resistance to Leishmania major in susceptible BALB/c mice. Nat Immunol 2001; 2:1054-60.

43. Dorner BG, Scheffold A, Rolph MS et al. MIP-1 $\alpha$, MIP-1 $\beta$, RANTES, and ATAC/lymphotactin function together with IFN- $\gamma$ as type 1 cytokines. Proc Natl Acad Sci USA 2002; 99:6181-6.

44. Ness JTL, Ewing L, Hogaboarn CM, Kunkelm SL. CCR4 is a key modulator of innate responses. J Immunol 2006; 177:7531-9.

45. Vester B, Muller K, Solbach W, Laskay T. Early gene expression of NK cell-activating chemokines in mice resistant to Leishmania major. Infect Immun 1999; 67:3155-9.

46. Arase $\mathrm{H}$, Arase N, Saito T. Interferon gamma production by natural killer (NK) cells and NK1.1+ T cells upon NKR-P1 cross-linking. J Exp Med 1996; 183:2391-96.

47. Ji J, Sun J, Soong L. Impaired expression of inflammatory cytokines and chemokines at early stages of infection with Leishmania amazonensis. Infect Immun 2003; 71:4278-88.

48. Varin A, Gordon S. Alternative activation of macrophages: immune function and cellular biology. Immunobiol 2009; 214:630-41.

49. Weiss G, Bogdan C, Hentze MW. Pathways for the regulation of macrophage iron metabolism by the anti-inflammatory cytokines IL-4 and IL-13. J Immunol 1997; 158:420-5.

50. Reljic R, Stylianou E, Balu S, Ma JK. Cytokine interactions that determine the outcome of mycobacterial infection of macrophages. Cytokine 2010; 51:42-6.

51. de Oliveira CI, Teixeira MJ, Teixeira CR et al. A. Leishmania braziliensis isolates differing at the genome level display distinctive features in BALB/c mice. Microbes Infect 2004; 6:977-84. 